\title{
Further evaluation of an updated PCR assay for the detection of Schistosoma mansoni DNA in human stool samples
}

\author{
Luciana I Gomes', Letícia HS Marques', Martin J Enk², Paulo Marcos Z Coelho², Ana Rabello1/+ \\ 'Laboratório de Pesquisas Clínicas 2Laboratório de Esquistossomose, Instituto de Pesquisas René Rachou-Fiocruz, \\ Av. Augusto de Lima 1715, 30190-002 Belo Horizonte, MG, Brasil
}

\begin{abstract}
A previously reported sensitive PCR assay for the detection of Schistosoma mansoni DNA was updated and evaluated. Changes in the DNA extraction method, including the use of a worldwide available commercial kit and the inclusion of additional quality control measures, increased the robustness of the test, as confirmed by the analysis of 67 faecal samples from an endemic area in Brazil. The PCR assay is at hand as a proven, reliable diagnostic test for the control of schistosomiasis in specific settings.
\end{abstract}

Key words: schistosomiasis - molecular diagnosis - faecal samples - polymerase chain reaction

Although the PCR technique has been extensively utilised for the diagnosis of numerous human diseases, its application for neglected diseases, especially schistosomiasis, has only recently been explored. Pontes et al. (2002) reported the first use of PCR for the diagnosis of Schistosoma mansoni DNA in faecal samples. High sensitivity and specificity rates were observed by this (Pontes et al. 2003) and another group (Allam et al. 2009) when compared to routine parasitological examination according to the Kato-Katz method (Katz et al. 1972).

When using in-house techniques, the molecular methods may suffer from a lack of standardization and robustness. Both of these criteria are emphatically required for any possible application by control programs in the field, where decisions should not be made based on investigational results. In this note, the Schistosoma PCR assay is updated to explain the modifications introduced during the last few years that resulted in increased robustness and reproducibility.

To further evaluate the modified method, 67 faecal specimens from a group composed of 27 children (female/male: 13/14; age range of 6-18 years) and 40 adult (female/male: 20/20; age range of 19-89 years) residents of Chonim de Cima, an endemic area in state of Minas Gerais, Brazil were analyzed. From the same sample, six slides were examined in search of parasite eggs by the parasitological Kato-Katz technique. This study was approved by the Ethical Committee of the Instituto de Pesquisas René Rachou-Fiocruz, Brazil (CEPSH: 03/2006). Individuals with positive faecal samples detected by the

Financial support: FIOCRUZ (Program for Technical Development of Health Inputs), CNPq, FAPEMIG

+ Corresponding author: ana@cpqrr.fiocruz.br

Received 12 August 2009

Accepted 28 October 2009
Kato-Katz technique were treated with a single oral dose of praziquantel (60 or $50 \mathrm{mg} / \mathrm{kg}$ for adults and children, respectively), according to the recommendation of the Brazilian Health Ministry.

The alternative DNA extraction procedure used the QIAamp DNA Stool Mini Kit (Qiagen GmbH, Hilden, Germany) according to the manufacturer's recommendations and following the protocols DNA Isolation from Large Amounts of Stool and Isolation of DNA from Stool for Pathogen Detection. Total DNA was extracted from $500 \mathrm{mg}$ of the 67 faecal specimens and from a saline solution containing 2,000 eggs of $S$. mansoni, used for determining the detection limit of the PCR assay. The heating step was performed at $95^{\circ} \mathrm{C}$ for $20 \mathrm{~min}$. The concentration and purity of the DNA were determined spectrophotometrically by readings of $A_{260}$ and $A_{280}$ (Eppendorf, Hamburg, Germany).

Faecal samples are known to be heterogeneous and therefore difficult to use in molecular analysis. In this study, the QIAamp ${ }^{\circledR}$ DNA Stool Mini Kit proved to be efficient. This worldwide available commercial kit allows the heating of the sample until $95^{\circ} \mathrm{C}$ to facilitate the rupture of the egg and cellular lysis. It also includes Inhibitex, which adsorbs DNA-damaging substances and PCR inhibitors present in the faecal material. Thus, for amplification, the DNA samples were diluted only 5-fold with good reproducibility.

DNA samples were amplified using the forward (5'GATCTGAATCCGACCAACCG-3') and reverse (5'ATATTAACGCCCACGCTCTC-3') primers designed by Pontes et al. (2002), which generate a 110 base pair product following the amplification procedure. For faecal amplification, DNA samples were diluted 5-fold and $2 \mu \mathrm{L}$ were used as template. The same volume was used to amplify egg-derived DNA. The PCR was carried out in a final volume of $20 \mu \mathrm{L}$ containing $2.0 \mathrm{U}$ of Platinum Taq DNA Polymerase (Invitrogen, São Paulo, Brazil), 1X PCR Buffer (200 mM Tris-HCl, pH 8.4, $500 \mathrm{mM}$ KCL - Invitrogen), $2.0 \mu \mathrm{g}$ bovine serum albumin (BSA) (Sigma, Saint Louis, Missouri), 0.6 $\mu \mathrm{M}$ of (each) primer, $2.0 \mathrm{mM} \mathrm{MgCl}_{2}$ and $200 \mu \mathrm{M}$ of each dNTP (Promega, 
Madison, WI). The PCR cycling program started with a pre-incubation at $95^{\circ} \mathrm{C}$ for $5 \mathrm{~min}$, followed by $14 \mathrm{cy}$ cles of $95^{\circ} \mathrm{C}$ for $40 \mathrm{sec}$ and $63^{\circ} \mathrm{C}$ for $30 \mathrm{sec}, 13$ cycles of $80^{\circ} \mathrm{C}$ for $40 \mathrm{sec}$ and $63^{\circ} \mathrm{C}$ for $30 \mathrm{sec}, 11$ cycles of $80^{\circ} \mathrm{C}$ for $40 \mathrm{sec}$ and $65^{\circ} \mathrm{C}$ for $30 \mathrm{sec}$ and a final elongation step at $72^{\circ} \mathrm{C}$ for $5 \mathrm{~min}$.

The hot-start properties of the DNA polymerase used in this assay prevent the non-specific amplification that can occur due to polymerase activity at suboptimal temperatures during cycle initiation and guarantee a good analytical specificity. Furthermore, BSA was added to the PCR mix in order to stabilise the DNA polymerase and neutralise contaminating inhibitors. A two-stage cycling protocol was performed to improve the analytical sensitivity of the method. This protocol was chosen because most amplification occurs during the first stage (annealing at $63^{\circ} \mathrm{C}$ ) and a thermally separated second stage with higher annealing temperature $\left(65^{\circ} \mathrm{C}\right)$ for a lower number of cycles prevents high background due to the accumulation of primer oligomers.

Drastic physical methods (separation of rooms and materials, use of bleach and laminar flux chamber with UV light) were applied during the procedure to minimise the chance of sample contamination. A carryover prevention method was also incorporated using uracil DNA glycosylase (UDG), an enzyme that cleaves the uracil base from the phosphodiester backbone of uracilcontaining PCR products prior to amplification, without effect on natural (i.e., thymine-containing) DNA. Contaminating PCR products from previous laboratory experiments (in which dTTP was replaced with dUTP) are degraded by UDG, thus eliminating this potential contamination route (Longo et al. 1990, Schwab \& McDevitt 2003). Consequently, 0.5 U of UDG (Invitrogen) and $400 \mu \mathrm{M}$ dATP, dCTP and dGTP, $800 \mu \mathrm{M}$ of dUTP (Promega) were added to the PCR master mix. The cycling program was preceded by a 10 -min incubation at $37^{\circ} \mathrm{C}$ (UDG digestion period) and a $15-\mathrm{min}$ incubation at $95^{\circ} \mathrm{C}$ (Platinum Taq activation and UDG inactivation). Additionally, after the final cycle, the samples were held at $72^{\circ} \mathrm{C}$ or stored immediately at $-20^{\circ} \mathrm{C}$ to prevent residual UDG catalytic activity.

As an internal quality control measure for the DNA isolation procedure and to test for the possible presence of PCR reaction inhibitors, all clinical samples were PCR-amplified for the human beta actin gene (ACTB) with the primers Aco1 and Aco2 (Musso et al. 1996). Five microlitres of the PCR-amplified material was subjected to electrophoresis on a $6 \%$ polyacrylamide gel and analyzed by silver staining.

The PCR analytical sensitivity was evaluated using 10-fold serial dilutions ranging from $3 \mathrm{ng}-300 \mathrm{ag}$ of genomic DNA extracted from the eggs of $S$. mansoni. The detection limit was $3 \mathrm{fg}$ of genomic DNA. Since the genome of $S$. mansoni contains $~ 580 \mathrm{fg}$ of DNA, this is equivalent to less than a single cell of this multi-cellular parasite (Gomes et al. 2006).

The efficiency of the UDG digestion system was determined through the addition of purified $S$. mansoni PCR product containing dUTP instead of dTTP (ranging from $0.2 \mathrm{ng}-2 \mathrm{fg}$ ) to a new PCR reaction to mimic accidental contamination. The UDG system was able to prevent the subsequent reamplification of high levels (20 fg or $1.5 \times 10^{5}$ copies) of uracil-containing PCR product. This modified protocol did not change the performance of the method and maintained the detection limit of $3 \mathrm{fg}$ of $S$. mansoni genomic DNA.

Diagnostic parameters of the above-described new PCR assay procedure were established using faecal samples from 67 inhabitants of an endemic area in Brazil. The positivity ratio observed using the PCR technique (61.2\%) was higher than that determined with the examination of six slides by the Kato-Katz technique (41.8\%) $\left(X^{2}=5.05, p=0.024\right)$. The geometric mean number of eggs per gram of faeces estimated by the Kato-Katz technique for the positive samples was 38 eggs per gram of faeces, which indicates a low intensity of infection. Table I depicts a direct comparison of the results obtained with the optimised PCR and the Kato-Katz technique. The Kappa index (Landis \& Koch 1977) of 0.511 indicates a moderate agreement between the two methods. The analysis of discordant results revealed that 15 samples were positive only by the PCR and two samples were positive only by the Kato-Katz technique. These two patients had very low egg outputs (4 and 8 eggs per gram of faeces). A number of reasons may contribute to the two negative results of PCR, including variations in egg output and the uneven distribution of eggs in

\section{TABLE I}

Comparative evaluation of the PCR and the Kato-Katz technique for the diagnosis of Schistosoma mansoni infection

\begin{tabular}{lccc}
\hline & \multicolumn{3}{c}{ Kato-Katz faecal examination } \\
\cline { 2 - 4 } & Positive & Negative & Total \\
\hline PCR & & & \\
Positive & 26 & 15 & 41 \\
Negative & 2 & 24 & 26 \\
Total & 28 & 39 & 67
\end{tabular}

Kappa index: 0.511.

TABLE II

Sensitivity and specificity values of the Kato-Katz and the PCR methods for the diagnosis of Schistosoma mansoni infection

\begin{tabular}{lcccc}
\hline & \multicolumn{2}{c}{$\begin{array}{c}\text { Sensitivity } \\
\%\end{array}$} & \multicolumn{2}{c}{$\begin{array}{c}\text { Specificity } \\
\%\end{array}$} \\
\cline { 2 - 5 } & $\mathrm{a}$ & $\mathrm{b}$ & $\mathrm{a}$ & $\mathrm{b}$ \\
\hline Kato-Katz & 100 & 65.1 & 100 & 100 \\
PCR & 92.9 & 95.3 & 61.5 & 100 \\
\hline
\end{tabular}

a: approach 1 (values calculated considering Kato-Katz results as the reference gold standard); b: approach 2 (values calculated assuming a specificity of $100 \%$ for both methods and defining all persons with a positive result by either method as infected). 
faeces (Engels et al. 1996). DNA degradation and the presence of PCR inhibitors, two other possible reasons, were eliminated, since both samples produced positive results for the amplification of the ACTB gene.

Test parameters were calculated by two different approaches: (i) using results of the Kato-Katz method as reference for comparison or (ii) as an exercise, considering the specificity of both the Kato-Katz and PCR method as being $100 \%$ and assuming that an infected person is everyone with a positive result by either method (Table II). The sensitivity values of PCR were high irrespective of the reference considered: 92.9\% (95\% CI 75.098.8) for approach 1 and 95.3\% (95\% CI 82.9-99.2) for approach 2 . The specificity values changed significantly depending on the reference used, with a value of $61.5 \%$ (95\% CI 44.7-76.2) for approach 1. In approach 2, the Kato-Katz technique and PCR were considered to have specificities of $100 \%$. The validity of this approach depends solely on the capability of the PCR to detect true positive samples, since that of the Kato-Katz technique has been established. However, all technical improvements described in this present study were carried out to increase the efficiency of PCR assay, contributing to a good analytical sensibility and specificity. Quality control measures, such as the use of DNA extraction and internal controls to prevent false-negative results, as well as the use of UDG to prevent carryover contamination and false-positive results, were adopted to ensure reliability to the assay.

In conclusion, the updated Schistosoma PCR-assay can be considered as a quality assured diagnostic test for use by control programs in endemic areas where adequate infrastructure exists and the need for more sensitive diagnostic methods is critical.

\section{ACKNOWLEDGMENTS}

To Aureo Almeida and Ana Maria Pacheco, for the excellent technical assistance.

\section{REFERENCES}

Allam AF, Kader O, Zaki A, Shehab AY, Farag HF 2009. Assessing the marginal error in diagnosis and cure of Schistosoma mansoni in areas of low endemicity using Percoll and PCR techniques. Trop Med Int Health 14: 316-321.

Engels D, Sinzinkayo E, Gryseels B 1996. Day-to-day egg count fluctuation in Schistosoma mansoni infection and its operational implications. Am J Trop Med Hyg 54: 319-324.

Gomes AL, Melo FL, Werkhauser RP, Abath FG 2006. Development of a real time polymerase chain reaction for quantitation of Schistosoma mansoni DNA. Mem Inst Oswaldo Cruz 101 (Suppl. I): 133-136.

Katz N, Chaves A, Pellegrino J 1972. A simple device for quantitative stool thick-smear technique in schistosomiasis mansoni. Rev Inst Med Trop Sao Paulo 14: 397-400.

Landis JR, Koch GG 1977. An application of hierarchical kappa-type statistics in the assessment of majority agreement among multiple observers. Biometrics 33: 363-374.

Longo N, Berninger MS, Hartley J L 1990. Use of uracil DNA glycosylase to control carry-over contamination in polymerase chain reaction. Gene 93: 125-128.

Musso O, Sommer P, Drouet E, Cotte L, Neyra M, Grimaud JA, Chevallier M 1996. In situ detection of human cytomegalovirus DNA in gastrointestinal biopsies from AIDS patients by means of various PCR-derived methods. J Virol Methods 56: 125-137.

Pontes LA, Dias-Neto E, Rabello A 2002. Detection by polymerase chain reaction of Schistosoma mansoni DNA in human serum and feces. Am J Trop Med Hyg 66: 157-162.

Pontes LA, Oliveira MC, Katz N, Dias-Neto E, Rabello A 2003. Comparison of a polymerase chain reaction and the Kato-Katz technique for diagnosing infection with Schistosoma mansoni. Am J Trop Med Hyg 68: 652-656.

Schwab KJ, McDevitt JJ 2003. Development of PCR enzyme immunoassay oligoprobe detection method for Toxoplasma gondii oocysts, incorporating PCR controls. Appl Environ 69: 5819-5825. 